\title{
Stimulus Effect of Nutrient Management Techniques with STCR in Field Pea Crop Cultivation under Irrigated Condition of Chandauli District, Uttar Pradesh, India
}

\author{
Kumar Rishi Ranjan", Y.V. Singh ${ }^{1}$, P. Dey ${ }^{2}$ and Sukirtee ${ }^{1}$ \\ ${ }^{1}$ AICRP on STCR, Department of Soil Science and Agricultural Chemistry, \\ Institute of Agricultural Sciences, Banaras Hindu University, \\ Varanasi 221005 (Uttar Pradesh), India \\ ${ }^{2}$ Project coordinator STCR (AICRP), Indian Institute of Soil Science, \\ Bhopal 462038 (Madhya Pradesh), India \\ *Corresponding author
}

A B S T R A C T

\section{Keywords}

STCR, Fertilizer, Pea, B:C ratio, Yield target

Article Info

\section{Accepted:}

05 February 2020

Available Online:

10 March 2020
A study is conducted through Soil test Crop Response based (STCR) for the desired yield targets of pea in an alluvial soil of two different locations of a village- Persiya, block- Naugharh in Chandauli district during Rabi season2017. For testing of developed fertilizer prescription equation is necessary to demonstrate the effectiveness of technology delivery to the farmers field. To evaluate the validation of fertilizer prescription, experiment was set-up in two locations of Chandauli district, Uttar Pradesh. Soil samples of the selected crop field locations are studied initially for analyzing available $\mathrm{N}, \mathrm{P}, \mathrm{K}, \mathrm{EC}, \mathrm{pH}$ and organic matter status. Treatments were included as control, farmer practices, general recommended dose of fertilizer and STCR based fertilizer dose with $5 \mathrm{t} \mathrm{ha}^{-1}$ FYM for targetingyield 15 and 20 quintal per hectare $\left(\mathrm{q} \mathrm{ha}^{-1}\right)$. The treatments were applied and cultivation practices were carried out periodically and the grain yield was recorded after harvest. With using data on grain yield and fertilizer doses applied, percent increment in yield and benefit cost (B:C) ratio were determined. The results of the experiments indicated that in two locations, the percent achievement of the targeted yield was within $\pm 10 \%$ variation proving the validity of the equations for prescribing integrated fertilizer doses for pea. The highest per cent increment in yield was recorded in the yield target of $20 \mathrm{q} \mathrm{ha}^{-1}$ (39.43 percent) followed by $15 \mathrm{q} \mathrm{ha}^{-1}$ (9.59 percent) over recommended dose of fertilizers (RDF). The highest mean grain yield recorded in STCR with $5 \mathrm{tha}^{-1}$ FYM was $20 \mathrm{q} \mathrm{ha}^{-1}(1962.5 \mathrm{~kg}$ $\left.\mathrm{ha}^{-1}\right)$. The highest benefit: cost ratio recorded in $\mathrm{T}_{5}$ treatment $\left(20 \mathrm{q} \mathrm{ha}^{-1}\right)$ was 5.45 followed by $\mathrm{T}_{4}$ treatment $\left(15 \mathrm{q} \mathrm{ha}^{-1}\right)$ was 4.32 . The fertilizer prescription equations developed for pea can be recommended for alluvial soil (Inceptisol) of eastern Utter Pradesh for achieving a yield target of $20 \mathrm{q} \mathrm{ha}^{-1}$ with higher economic return. 


\section{Introduction}

Field pea (Pisum sativum L.) is a leguminoceae family crop and commonly known as 'Matar' in India. It is widespread pulse crop in the world as like in India. It is consumed as green and yellow pea as a vegetable and pulse respectively. It contributes in human diet with protein (27.8\%), complex carbohydrates $(42.65 \%)$, vitamins, minerals, dietary fibers and antioxidant compounds (Urbano et al., 2003). The field peas are distributed in Asia, Africa, Europe, North America, Australia, China, Russian Fed, Ukraine, India, Ethiopia, France, Canada and USA, these are the leading field Pea producing countries contributing approximately $75 \%$ to the total global production. India is the second largest producer of pea in the world after Russia (Negi et al., 2004). The pea is full of nutrition because its grain is Pea is the third most important pulse crop at global level, after dry bean and chickpea and third most popular rabi pulse of India after chickpea and lentil. Uttar Pradesh is the major field pea growing state producing $60 \%$ of country's produce. There is no doubt, for increasing the crop production, fertilizer is one of the most essential agricultural inputs. Soil testing is now being accepted as a technique for recommending the fertilizer doses for various crops in India. But it would be beneficial only when it is based on right knowledge about the management practices with the interactions of these factors like soil, crop-variety, fertilizer and climate. (Kanwar, 1971). Use of plant nutrients based on soil test helps to get higher response ratio and benefit-cost ratio as the nutrient are applied in proportion to the magnitude of the deficiency of particular nutrient and the correction of the nutrients imbalance in soil helps to connect the synergistic effects of balanced fertilization (Rao and Srivastava, 2000). Soil test and crop response (STCR) method is created on soil contribution and yield level and used for recommending fertilizer dose. In 1967, All India Co-ordinated Research Project on STCR, the targeted yield concept is being widely followed. Targeted yield approach was first developed by (Troug, 1960) and (Ramamurthy et al., 1967). The IPNS based STCR equations are useful and decisive step towards appropriate dose of chemical fertilizers in combination with the decomposed manures.

\section{Materials and Methods}

To assess the validation of fertilizer prescription equation for pea developed by STCR model, field experiments were carried out in two different location of two farmers field of alluvial soil of Utter Pradesh. Experiments were set up at two locations in Persiya village, Naugarh block of Chandauli district, Utter Pradesh. Initial soil samples were collected from each location and analyzed for $\mathrm{pH}$ determination through 1:2.5 soil-water suspensions by potentiometer method (Jackson, 1973). Electrical conductivity was determined by using Conductivity Bridge (EC meter) and expressed in $\mathrm{dSm}^{-1}$ (Jackson, 1973). Organic carbon through titration method (Walkley and Black, 1934), available nitrogen (N) by alkaline permanganate method (Subbiah and Asija, 1956), phosphorus by Olsen-P reagent (Olsen et al., 1954), potassium (K) by normal ammonium acetate method (Hanway and Heidal, 1952). The initial soil fertility status for different locations is shown in Table 1.Fertilizer prescription equations developed for pea under STCR- IPNMS on eastern plain zone of Utter Pradesh by (Kumar et al., 2018), are given below:

Nitrogen dose $\left(\mathrm{kgha}^{-1}\right)=\mathrm{FN}=4.15 \mathrm{~T}-0.27 \mathrm{SN}$ $-0.09 \mathrm{ON}$

Phosphorus dose $\left(\mathrm{kg} \mathrm{ha}^{-1}\right)=\mathrm{FP}=3.18 \mathrm{~T}-2.08$ $\mathrm{SP}_{2} \mathrm{O}_{5}-0.12 \mathrm{OP}_{2} \mathrm{O}_{5}$ 
Potassium dose $\left(\mathrm{kg} \mathrm{ha}^{-1}\right)=\mathrm{FK}=4.31 \mathrm{~T}-0.32$ $\mathrm{SK}_{2} \mathrm{O}-0.14 \mathrm{OK}_{2} \mathrm{O}$

Where, $\mathrm{T}=$ Grain yield target in $\mathrm{q} \mathrm{ha}^{-1} ; \mathrm{SN}, \mathrm{SP}$ and $\mathrm{SK}$ are available $\mathrm{N}, \mathrm{P}$ and $\mathrm{K}$ through soil in $\mathrm{kg} \mathrm{ha}^{-1}$ whereas ON, OP and OK are N, P and $\mathrm{K}$ supplied through $\mathrm{FYM}$ in $\mathrm{kg} \mathrm{ha}{ }^{-1}$ respectively. The treatments executed were as follows: (i)Control $\left(\mathrm{T}_{1}\right)$, (ii) Farmer's Practices $\left(\mathrm{T}_{2}\right)$, (iii) General Recommended Dose( $\left.\mathrm{T}_{3}\right)$,(iv) STCR based fertilizer dose with $5 \mathrm{tha}^{-1}$ FYM for an yield target of $15 \mathrm{q}$ ha ${ }^{1}\left(\mathrm{~T}_{4}\right)$ and (v) STCR based fertilizer dose with $5 \mathrm{tha}^{-1}$ FYM for an yield target of $20 \mathrm{q} \mathrm{ha}$ ${ }^{1}\left(\mathrm{~T}_{5}\right)$. Based on the initial soil test values of available $\mathrm{N}, \mathrm{P}$ and $\mathrm{K}$ and the quantities of $\mathrm{N}$, $\mathrm{P}_{2} \mathrm{O}_{5}$ and $\mathrm{K}_{2} \mathrm{O}$ supplied fertilizer doses were calculated and suggested for STCR treatments for various yield targets.

Full dose of $\mathrm{N}, \mathrm{P}_{2} \mathrm{O}_{5}$ and $\mathrm{K}_{2} \mathrm{O}$ were applied initially and other packages of practices were carried out periodically. Using the data on grain yield and fertilizer doses applied, the parameters viz., B:C ratio was worked out based on the price of the produce and cost incurred for the cultivation as per the standard procedure.

\section{Results and Discussion}

The highest mean grain yield between the two farmers field were recorded in the treatment
STCR20q ha ${ }^{-1}\left(1962.5 \mathrm{~kg} \mathrm{ha}^{-1}\right)$ followed by STCR15q ha ${ }^{-1}\left(1542.5 \mathrm{~kg} \mathrm{ha}^{-1}\right)$, GRD ( 1407.5 $\mathrm{kg} \mathrm{ha}^{-1}$ ) and farmer practices (1075 $\mathrm{kg} \mathrm{ha}^{-1}$ ) indicating that the STCR treatment with $5 \mathrm{t}$ ha ${ }^{-1}$ FYM was recorded relatively higher yield over GRD and Farmer s practices (Table 3). Lowest yield recorded in controlled $(965.0 \mathrm{~kg}$ $\mathrm{ha}^{-1}$ ) compare to all other treatments. STCR20 $\mathrm{q} \mathrm{ha}^{-1}$ recorded a yield increase of $39.43 \%$ over general recommendation dose of fertilizer. All the treatments are significantly different in which STCR 20q ha ${ }^{-1}$ receive highest mean yield. In the two verification trials, the per cent achievement of the targeted yield was within $\pm 10 \%$ variation proving the validity of the equations for prescribing integrated fertilizer doses for pea. In STCR 20 q ha ${ }^{-1}$ (Rs.33718), which was highest net benefit found followed by STCR $15 \mathrm{qha}^{-1}$ (Rs.18760), GRD (Rs.14314) and farmer practices (Rs.3507). Highest B:C ratio was recorded in STCR $20 \mathrm{q} \mathrm{ha}^{-1}$ (5.45) followed by STCR $15 \mathrm{q} \mathrm{ha}^{-1}$ (4.32). So STCR treated field performed best overall viz., higher yield, net benefits and $\mathrm{B}: \mathrm{C}$ ratio compare to others treated field due to balanced supply of nutrients from fertilizer, efficient utilization of applied fertilizer nutrients in the presence of organic sources and the synergistic as well as beneficial effect of the conjoint addition of several sources of nutrients (Singh, 2019 and Singh et al., 2017).

Table.1 Initial soil fertility status of the different locations of Village-Persiya, Naugarh block in district Chandauli

\begin{tabular}{|c|c|c|c|c|c|c|c|}
\hline Locations & Farmers Name & pH & $\underset{\left(\mathbf{d S m}^{-1}\right)}{\text { E.C. }}$ & $\begin{array}{l}\text { OC } \\
(\%)\end{array}$ & $\begin{array}{l}\text { Avai. N } \\
\left(\mathrm{kg} \mathrm{ha}^{-1}\right)\end{array}$ & $\begin{array}{c}\text { Avai. P } \\
\left(\mathrm{kg} \mathrm{ha}^{-1}\right)\end{array}$ & $\begin{array}{l}\text { Avai. } K \\
\left(\mathrm{~kg} \mathrm{ha}^{-1}\right)\end{array}$ \\
\hline 1. & $\begin{array}{l}\text { Smt. Kishmati Devi w/o Shri } \\
\text { Ramlakhan }\end{array}$ & 7.28 & 0.41 & 0.71 & 182.00 & 20.90 & 179.90 \\
\hline 2. & Smt. Prabhawati w/o Shri Ganesh & 7.30 & 0.42 & 0.68 & 178.20 & 21.20 & 181.00 \\
\hline
\end{tabular}


Table.2 Treatments of fertilizer doses $\left(\mathrm{kg} \mathrm{ha}^{-1}\right)$ imposed under different locations of VillagePersiya, Naugarh block in district Chandauli

\begin{tabular}{|c|c|c|c|c|c|c|}
\hline \multirow[t]{2}{*}{ Treatments } & \multicolumn{3}{|c|}{ Location 1} & \multicolumn{3}{|c|}{ Location 2} \\
\hline & $\mathrm{N}$ & $\mathrm{P}$ & $\mathrm{K}$ & $\mathrm{N}$ & $\mathrm{P}$ & $\mathrm{K}$ \\
\hline Control & 0 & 0 & 0 & 0 & 0 & 0 \\
\hline Farmer's practice & 10 & 20 & 15 & 10 & 20 & 15 \\
\hline GRD & 20 & 40 & 30 & 20 & 40 & 30 \\
\hline STCR15 q ha & 19 & 27 & 20 & 19 & 27 & 20 \\
\hline STCR20 q ha & 40 & 43 & 41 & 40 & 43 & 41 \\
\hline
\end{tabular}

Where: GRD - General Recommended Dose and STCR-Soil Test Crop Response

Table.3 Grain yield, net benefits and B: C ratio of pea crop under different locations of VillagePersiya, Naugarh block in district Chandauli

\begin{tabular}{|c|c|c|c|c|c|c|c|c|}
\hline \multirow[t]{2}{*}{ Treatments } & \multicolumn{2}{|c|}{$\begin{array}{l}\text { Grain yield (kg } \\
\text { ha }^{-1} \text { ) Locations }\end{array}$} & \multirow[t]{2}{*}{$\begin{array}{c}\text { Mean } \\
\left(\text { kgha }^{-1}\right)\end{array}$} & \multirow{2}{*}{$\begin{array}{c}\text { Increment } \\
\text { in yield } \\
\text { over T }_{1} \\
\left(\mathrm{~kg} \mathrm{ha}^{-1}\right)\end{array}$} & \multirow{2}{*}{$\begin{array}{c}\text { Value of } \\
\text { additional } \\
\text { yield } \\
\text { (Rs.) }\end{array}$} & \multirow{2}{*}{$\begin{array}{l}\text { Cost of } \\
\text { fertilizer } \\
\text { (Rs.) }\end{array}$} & \multirow{2}{*}{$\begin{array}{c}\text { Net } \\
\text { benefit } \\
\text { (Rs.) }\end{array}$} & \multirow[t]{2}{*}{$\begin{array}{l}\mathrm{B} / \mathrm{C} \\
\text { ratio }\end{array}$} \\
\hline & 1 & 2 & & & & & & \\
\hline$T_{1-0-0-0}$ & 985 & 945 & 965.0 & - & - & - & - & - \\
\hline$T_{2}-10-20-15$ & 1,115 & 1075 & 1095.0 & 130 & 5200 & 1693 & 3507 & 2.07 \\
\hline $\begin{array}{c}T_{3}-20-40- \\
30\end{array}$ & 1,415 & 1400 & 1407.5 & 442.5 & 17700 & 3386 & 14314 & 4.23 \\
\hline $\begin{array}{c}\text { T4- } 19 \text { - } 27- \\
20-5\end{array}$ & 1,555 & 1530 & 1542.5 & 577.5 & 23100 & 4340 & 18760 & 4.32 \\
\hline $\begin{array}{c}T-40-43- \\
41-5\end{array}$ & 1,995 & 1930 & 1962.5 & 997.5 & 39900 & 6182 & 33718 & 5.45 \\
\hline C.D at $5 \%$ & 3.989 & 4.223 & & - & - & - & - & - \\
\hline
\end{tabular}

Note: Pea @Rs.40.00/kg, N@Rs.17.39/kg, $\mathrm{P}_{2} \mathrm{O}_{5} @ R s .56 .25 / \mathrm{kg}, \mathrm{K}_{2} \mathrm{O} @ \mathrm{Rs} .26 .66 / \mathrm{kg}$

$\mathrm{T}_{1}$ - Control, $\mathrm{T}_{2}$ - Farmer's Practices, $\mathrm{T}_{3}$ - GRD (General recommended Dose)

$\mathrm{T}_{4}$ - Target yield (1500 $\left.\mathrm{kg} \mathrm{ha}^{-1}\right)$ with FYM $5 \mathrm{t} \mathrm{ha}^{-1}$ and $\mathrm{T}_{5^{-}}$Target yield $\left(2000 \mathrm{~kg} \mathrm{ha}^{-1}\right)$ with FYM $5 \mathrm{t} \mathrm{ha}^{-1}$ 
Table.4 Post-harvest soil fertility status of various treatments under different locations of village-Persiya, Naugarh block in district Chandauli

\begin{tabular}{|c|c|c|c|c|c|c|}
\hline \multirow{2}{*}{ Treatments } & \multicolumn{3}{|c|}{ Location 1 } & \multicolumn{3}{c|}{ Location 2 } \\
\cline { 2 - 7 } & $\mathrm{N}$ & $\mathrm{P}$ & $\mathrm{K}$ & $\mathrm{N}$ & $\mathrm{P}$ & $\mathrm{K}$ \\
\hline Control & 211 & 16.2 & 192 & 209 & 16.5 & 190 \\
\hline Farmer's practice & 224 & 18.3 & 201 & 223 & 17.2 & 198 \\
\hline GRD & 237 & 19.1 & 203 & 228 & 18.4 & 203 \\
\hline STCR 15 q ha & 241 & 19.7 & 211 & 233 & 19.8 & 211 \\
\hline STCR 20 q ha & 246 & 21.9 & 214 & 241 & 21.5 & 213 \\
\hline CD at 5\% & 3.97 & 2.07 & 4.23 & 6.47 & 1.56 & 4.78 \\
\hline
\end{tabular}

Where: GRD - General recommended dose and STCR-Soil teat crop response

Post-harvest soil values revealed that a sufficient build up and maintenance of SN, SP and SK are found under STCR study compare to farmer practices and general recommended dose. Despite removal of higher amount of nutrient in STCR treatment due to getting a higher yield, higher post-harvest soil fertility was observed in STCR plot. The highest postharvest soil nitrogen, phosphorus and potassium found in STCR for $20 \mathrm{q} \mathrm{ha}^{-1}$ were $246.00 \mathrm{~kg} \mathrm{ha}^{-1}, 21.90 \mathrm{~kg} \mathrm{ha}^{-1}$ and $214 \mathrm{~kg} \mathrm{ha}^{-1}$ in location-1, respectively shown in table 4 . Higher consistent profit with maintaining soil fertility status was realized when fertilizer was applied for suitable yield targets in succession over years using STCR concept (Singh et al. 2015).The greater buildup of nutrient in STCR treated field was due to balance application of chemical fertilizer in conjoint with organic manure source. Combination of FYM organic source with fertilizers improved the chemical and physical properties, which led to enhance and sustainable crop production.

On the basis of results of experiment which we found, we can say that the study will help to make guidelines for the amount of fertilizer used in field pea cultivation. The specific yield equation based on soil health will not only ensure sustainable crop production but will also steer the farmers towards economic use of costly fertilizer inputs depending on their financial status and prevailing market price of the crop under consideration.

\section{Acknowledgement}

The authors are grateful to Indian Institute of Soil Sciences, Bhopal for providing financial assistance through AICRP on STCR project during the farmers' field experiment.

\section{References}

Hanway, J.J., Heidal, H. Soil analysis methods as used in Iowa State CollegeSoil Testing Laboratory. Iowa State College Bull 1952; 57, 1-131.

Jackson, M.L. Soil Chemical Analysis. Prentice Hall of India Pvt. Ltd. New Delhi 1973.

Kanwar, J. S. Soil Testing Service in India retrospect and prospect. Proceedings of international symposium on soil fertility evaluation. New Delhi 1971; I:11031113.

Kumar Rishi Ranjan, Y.V. Singh, S.K. Singh and P. Dey. Fertilizer Recommendations Developed through Soil Test Crop Response Studies with Integrated Plant Nutrient Management System for Field Pea in an Inceptisol. Journal of the Indian Society of Soil 
Science 2018; 66(3): 318-323.

Negi, Susheela, Singh, R.V. and Dwivedi, G.K. Effect of biofertilizers, FYM, NPK and lime on pea in acidic soil of Uttaranchal hills. Vegetable Science 2004; 31:193 -195.

Olsen, S.R., Cole, C.V., Watanabe, F.S., Dean, L. Estimation of available phosphorus in soils by extraction with sodium bicarbonate (USDA Circular 939). Washington, D. C.: U. S. Government Printing Office 1954.

Ramamoorthy, B., Narasimham., R.L. and Dinesh, R.S. Fertilizer application for specific yield targets on Sonora 64 (wheat). Indian Farming 1967; 17: 43 45.

Rao, A. S., and Srivastava, S. Soil Test Based Fertilizer Use-a must for Sustainable Agriculture. Fertilizer News 2000; 45:25-38.

Singh, Y. V. Target Yield through Soil Test Crop Response Technology of Wheat in Chandauli district of Uttar Pradesh. Technofame - A Journal of Multidisciplinary Advance Research 2019; 8 (1): 1-6.

Singh, Y.V. and Dey, Pradip., S.K., Singh and Kumar, Mukesh. Impact of soil test crop response technology on yield and economics of wheat in Chandauli district of Uttar Pradesh. Technofame A Journal of Multidisciplinary Advance Research 2015;1: 52 - 56.

Singh, Y.V., Singh, S.K. and Dey, Pradip. Nutrient Management for Chick pea Using Soil Test Target Yield Equation in Hadahi village, Chandauli district of Uttar Pradesh. Technofame - A Journal of Multidisciplinary Advance Research 2017;6(1): 153-157.

Subbiah, B.V. and Asija, G.L. A rapid procedure for estimation of available nitrogen in soils. Current Science 1956; 25: 259-60.

Truog, E. Fifty years of soil testing. Proc. Trans 7th International congress soil science 1960;III-IV (7):46-53

Urbano, G. P., Aranda and Villalva, E. G. Nutritional evaluation of pea (Pisum sativum L.) protein diets after mild hydrothermal treatment and with and without added phytase. Journal of Agricultural and Food Chemistry 2003; 51: 2415-2420.

Walkley. A. and Black I.A. An Examination of the Degtjareff Method for Determining Soil Organic Matter, and a Proposed Modification of the Chromic Acid Titration Method. Soil Science 1934; 27: 29-38.

\section{How to cite this article:}

Kumar Rishi Ranjan, Y.V. Singh, P. Dey and Sukirtee. 2020. Stimulus Effect of Nutrient Management Techniques with STCR in Field Pea Crop Cultivation under Irrigated Condition of Chandauli District, Uttar Pradesh, India. Int.J.Curr.Microbiol.App.Sci. 9(03): 96-101. doi: https://doi.org/10.20546/ijcmas.2020.903.012 